\title{
Comparisons of Uniform and Discrete Source Distributions for Use in Bioassay Laboratory Performance Testing
}

\author{
R. I. Scherpelz \\ J. A. MacLellan \\ J. M. Selby, PNL. Program Manager \\ E. J. Vallario, DOE Program Manager
}

September 1987

Prepared for

the U.S. Department of Energy

Assistant Secretary for

Environment, Safety, and Health

under Contract DE-AC06-76RLO 1830

Pacific Northwest Laboratory

Operated for the U.S. Department of Energy

by Battelle Memorial Institute 


\title{
DISCLAIMER
}

This report was prepared as an account of work sponsored by an agency of the United States Government. Neither the United States Government nor any agency thereof, nor Battelle Memorial Institute, nor any of their employees, makes any warranty, expressed or implied, or assumes any legal liability or responsibility for the accuracy, completeness, or usefulness of any information, apparatus, product, or process disclosed, or represents that its use would not infringe privately owned rights. Reference herein to any specific commercial product, process, or service by trade name, trademark, manufacturer, or otherwise, does not necessarily constitute or imply its endorsement, recommendation, or favoring by the United States Government of any agency thereof, or Battelle Memorial Institute. The views and opinions of authors expressed herein do not necessarly state or reflect those of the United States Government or any agency thereof, or Battelle Memorial Institute.

\author{
PACIFIC NORTHWEST LABORATORY \\ operated by \\ BATTELLE MEMORIAL INSTITUTE \\ for the \\ UNITED STATES DEPARTMENT OF ENERGY \\ under Contract DE-AC06-76RLO 1830
}

\begin{tabular}{|c|c|}
\hline \multicolumn{2}{|c|}{$\begin{array}{c}\text { National Technical Information Service } \\
\text { United States Department of Commerce } \\
5285 \text { Port Royal Road } \\
\text { Springfield, Virginia } 22161\end{array}$} \\
\hline \multicolumn{2}{|c|}{$\begin{array}{l}\text { NTIS Price Codes } \\
\text { Microfiche A01 }\end{array}$} \\
\hline \multicolumn{2}{|c|}{ Printed Copy } \\
\hline Pages & $\begin{array}{l}\text { Price } \\
\text { Codes }\end{array}$ \\
\hline $001-025$ & $\mathrm{~A} 02$ \\
\hline $026-050$ & $\mathrm{~A} 03$ \\
\hline $051-075$ & A04 \\
\hline $076-100$ & A05 \\
\hline $101-125$ & $A 06$ \\
\hline $126-150$ & $A 07$ \\
\hline $151-175$ & A08 \\
\hline $176-200$ & $\mathrm{~A} 09$ \\
\hline $201-225$ & A010 \\
\hline $226-250$ & A011 \\
\hline $251-275$ & A012 \\
\hline $276-300$ & A013 \\
\hline
\end{tabular}


COMPARISONS OF UNIFORM AND DISCRETE SOURCE DISTRIBUTIONS FOR USE IN BIOASSAY LABORATORY PERFORMANCE TESTING

R. I. Scherpe]z

J. A. MacLellan

J. M. Selby, PNL Program Manager

E. J. Vallario, DOE Program Manager

September 1987

Prepared for

the U.S. Department of Energy

Assistant Secretary for

Environment, Safety, and Hea? th

under Contract DE-ACO6-76RLO 1830

Pacific Northwest Laboratory

Richland, Washington 99352 


\section{FOREWORD}

In recent years the U.S. Department of Energy (DOE), Office of Nuclear Safety, has sponsored research to improve occupational radiation protection at its facilities. Of particular concern have been the accuracy, quality control, and performance of personnel radiation dosimeters, radiation survey instruments, and bioassay laboratories.

The work described in this report was developed as a resuit of testing current measurement capabilities of bioassay laboratories. The performance testing was part of a larger project that is evaluating the appropriateness of draft American National Standards Institute (ANSI) Standard N13.30, "Performance Criteria for Radiobioassay Laboratories,"

This report describes computer simulation work that was designed to determine the appropriateness of using discrete radioactive sources in a bioassay phantom to approximate a uniform distribution of material. The results will be incorporated when an accreditation program for DOE bioassay laboratories is established.

E.J. ValTario, Acting Director

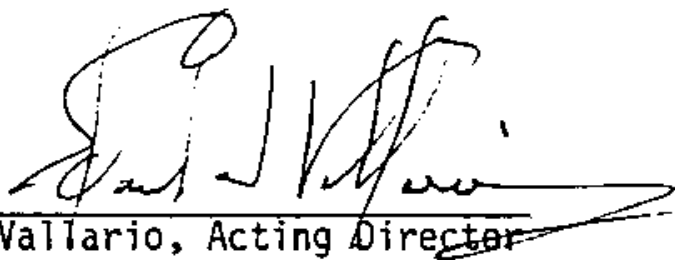

Radiological Controls Division

Office of Nuclear Safety

U.S. Department of Energy 


\section{EXECUTIVE SUMMARY}

As part of evaluating the performance criteria of the draft American National Standards Institute (ANSI) standard on bioassay laboratory performance, draft ANSI Standard N13.30, "Performance Criteria for Radiobioassay," the Pacific Northwest Laboratory (PNL) is sending a torso phantom with radioactive material uniformly distributed in the lungs to in vivo bioassay laboratories for analysis. During development of the test protocol, the investigators became concerned over the proposed use of short half-life nuclides. If, during the testing round, the nuclide in the lungs decayed to a level close to the detection capabilities of the laboratories, results from laboratories scheduled to assay the phantom early in the round could not be meaningfulty compared to results from laboratories scheduled to assay the phantom later in the round. This is because the associated relative errors would increase as the sample activity approached the laboratory's minimum detectable amount.

Although the radionuclides ultimately chosen for the studies had relatively long half-lives, future accreditation testing will require repeated tests with short half-iife test nuclides. The investigators proposed to allow substitution of lung sets containing plugs of radioactive material for lung sets with uniformly distributed sources. The plugs could then be easily exchanged to maintain the desired activity level.

Computer modeling was used to simulate the major components of the phantom. Radiation transport calculations were then performed using the computer models to calculate dose rates either $15 \mathrm{~cm}$ from the chest or at its surface. The computer simulation compared plug-loaded phantoms to phantoms containing a uniform distribution of $144 \mathrm{Ce}, 60 \mathrm{Co}$, and $40 \mathrm{~K}$. The $144 \mathrm{Ce}$ and $50 \mathrm{Co}$ loaded in plugs were compared with uniformly distributed phantom lungs, while the plugloaded $40 \mathrm{~K}$ was compared with uniform distributions inside the chest wall and throughout the lungs.

The simulated $40 \mathrm{~K}$ plug was located at the back of the lower heart region. The plug was assumed to contain $80 \mathrm{nCi}$ of $40 \mathrm{~K}$ distributed uniformly throughout 
the plug. In the calculation with the heart plug in place, no other radioactive sources were assumed to be in the phantom.

For ${ }^{144} \mathrm{Ce}$ and ${ }^{60} \mathrm{Co}$, three configurations were used for the lung comparison tests. To provide a direct comparison, the total activity in each lung was assumed to be $320 \mathrm{nCi}$. In the first case, there were 4 source plugs in each lung with $80 \mathrm{nCi}$ per plug. In the second case, there were 16 plugs in each lung, so each plug was assumed to contain $20 \mathrm{nCi}$. In the third case, each lung was assumed to contain 32 plugs with $10 \mathrm{nCi}$ apiece. The locations of the source plugs were chosen to make spacing in the lung regions as even as possible.

Calculations show that, for most detector positions, a single plug containing ${ }^{40} \mathrm{~K}$ located in the back of the heart provides a good approximation to a uniform distribution of ${ }^{40} \mathrm{~K}$. The approximation would lead, however, to a positive bias for the detector reading if the detector were located at the chest surface near the center. This location results in the least distance and attenuating material between the plug and the detector. Thus, the plug gives a dose rate with $95 \%$ positive bias. For other detector locations, this geometry effect is less pronounced and the bias is usually within $5 \%$ (except with the detector over the right lung, where it is $14 \%$ low).

Loading the ${ }^{40} \mathrm{~K}$ in a uniform layer inside the chest wall is not a good approximation of the uniform distribution in the lungs, because most of the radionuclides would be situated close to the detector location and the only shielding would be the thickness of the chest wall. This distribution, therefore, gives dose rates to detector locations at the chest wall that are three to four times higher than the uniform distribution in the lungs.

The calculated dose rates for ${ }^{60} \mathrm{Co}$ and ${ }^{144} \mathrm{Ce}$ were similar at all calculated reference points. For both nuclides, any type of plug loading resulted in a good approximation of the uniform distribution for dose points $15 \mathrm{~cm}$ from the chest wall. For these locations, most relative biases were under $2 \%$, with the highest being $4 \%$. At the chest wall, biases up to $17 \%$ were calculated.

Plug loading is an acceptable alternative to uniform source distribution only when the measurement system incorporates a detector that is $15 \mathrm{~cm}$ or more 
from the chest surface. When detectors are at or near the chest surface, biases up to $17 \%$ are predicted and compliance with the overall error of less than $5 \%$ specified in draft ANSI N13.30 cannot be ensured. Since the procedure - used by the testing laboratory must be the same for all laboratories tested, plug source loading of phantoms used for bioassay laboratory performance testing is not recommended. 


\section{CONTENTS}

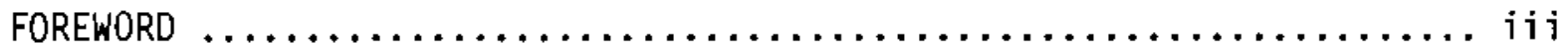

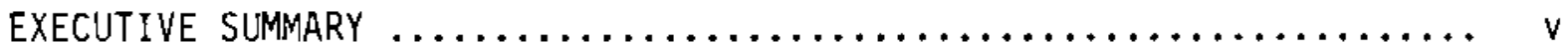

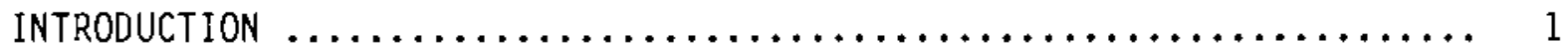

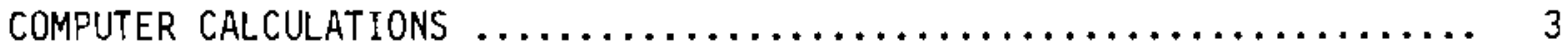

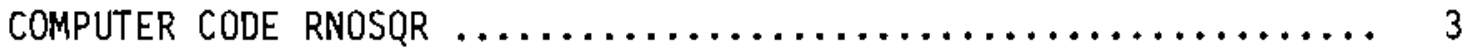

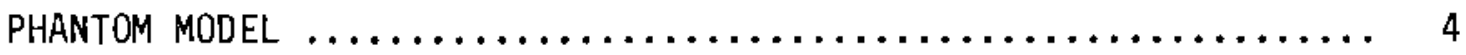

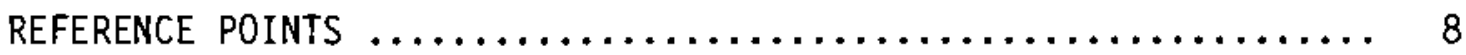

SOURCE PLUGS $\ldots \ldots \ldots \ldots \ldots \ldots \ldots \ldots \ldots \ldots \ldots \ldots \ldots \ldots \ldots \ldots, 8$

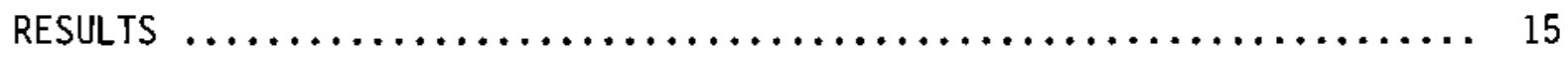

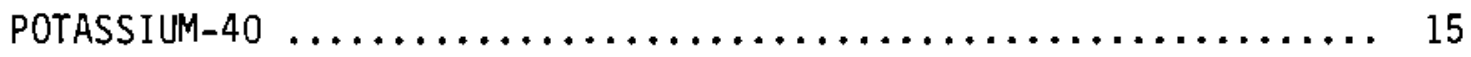

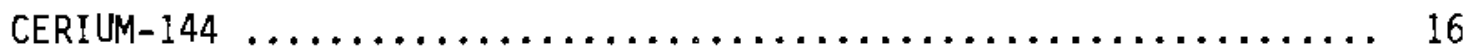

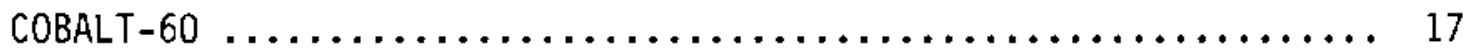

CONCLUSIONS AND RECOMMENDATIONS $\ldots \ldots \ldots \ldots \ldots \ldots \ldots \ldots \ldots \ldots \ldots \ldots \ldots \ldots \ldots \ldots \ldots \ldots$

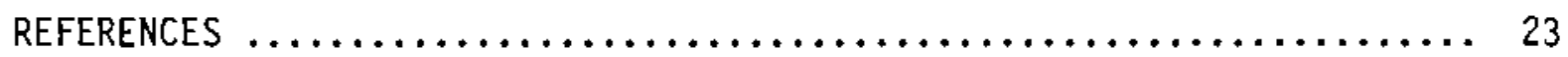





\section{$\underline{\text { FIGURES }}$}

1 Orientation of Modeled Regions, $x-y$ Plane $\ldots \ldots \ldots \ldots \ldots \ldots \ldots$

2 Orientation of Modeled Regions, $y-z$ Plane $\ldots \ldots \ldots \ldots \ldots \ldots \ldots$

3 Orientation of the Modeled Lower Heart Region $\ldots . \ldots \ldots \ldots \ldots \ldots . . . .9$

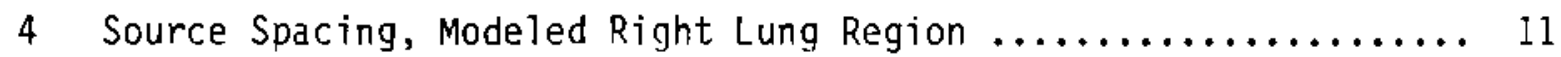

5 Source Spacing, Modeled Left Lung Region ................ 12

\section{TABLES}

1 Dimensions of Regions in the Phantom Model $\ldots \ldots \ldots \ldots \ldots$

2 Positioning Coordinates for Lung Phantom Regions .......... 8

3 Reference Point Coordinates $\ldots \ldots \ldots \ldots \ldots \ldots \ldots \ldots \ldots \ldots \ldots$

4 Source Plug Locations Used in Calculations ............... 14

5 Calculated Dose Rates from ${ }^{40} \mathrm{~K} \ldots \ldots \ldots \ldots \ldots \ldots \ldots \ldots \ldots$

6 Comparison of Dose Rates from ${ }^{40} \mathrm{~K} \ldots \ldots \ldots \ldots \ldots \ldots \ldots$

7 Calculated Dose Rates from ${ }^{144} \mathrm{Ce} \ldots \ldots \ldots \ldots \ldots \ldots \ldots \ldots \ldots$

8 Relative Bias in Calculated Dose Rates from ${ }^{144} \mathrm{Ce} \ldots \ldots \ldots \ldots . . .17$

9 Calculated Dose Rates from ${ }^{60} \mathrm{Co}_{0} \ldots \ldots \ldots \ldots \ldots \ldots \ldots \ldots \ldots$

10 Relative Bias in Calculated Dose Rates from ${ }^{60} \mathrm{Co} \ldots \ldots \ldots \ldots$ 



\section{INTRODUCTION}

The work described in this document was performed by the Pacific Northwest Laboratory (PNL) ${ }^{(a)}$ in support of a project sponsored by the U.S. Department of Energy (DOE) to evaluate the performance criteria of the draft American National Standards Institute (ANSI) Standard N13.30, "Performance Criteria for Radiobioassay. "(b) The bioassay standard evaluation project is a nationwide, two-round study to test the analytical performance of in vivo bioassay laboratories and to determine the appropriateness of the performance criteria specified in the draft standard for DOE facilities.

In the intercomparison studies, a torso phantom with uniformly distributed radioactive material in the lungs was sent to in vivo bioassay laboratories for analysis. Because the phantom was to be circulated to over 20 laboratories one at a time, the concern of the investigators increased regarding the use of short half-life nuclides. If the nuclide in the lungs decayed during the testing round to a level close to the detection capabilities of the laboratories, results from laboratories scheduled to assay the phantom early in the round could not be meaningfuliy compared to laboratories receiving the phantom later in the round because the associated relative errors would increase as the sample activity approached the laboratory's minimum detectable amount. To solve this problem, the investigators proposed that lung sets containing plugs of radioactive material be substituted for the lung sets with uniformly distributed sources. The plugs could then be easily exchanged to maintain the desired activity level.

The purpose of the work described in this report was to estimate the magnitude of the biases that would result if plug-loaded lungs were subtituted for lung sets with a uniform source distribution. The first section of this report describes the computer modeling used to test for biases introduced by nonuniform loadings. The computer code uses radiation transport calculations

\footnotetext{
(a) PNL is operated for the U.S. Department of Energy by Battelle Memorial Institute under Contract DE-AC06-76RLO 1830.

(b) Information on draft ANSI Standard N13.3D is available from Roscoe Ha11, Savannah River Plant.
} 
to compare simulated radiation transmission from equally spaced plugs to transmission from uniformly distributed activity. Reference Man lungs, heart, and chest wall (ICRP 1975) were modeled using regular geometric shapes. The report describes radiations from three nuclides $\left({ }^{40} \mathrm{~K},{ }^{144} \mathrm{Ce}\right.$, and $\left.{ }^{60} \mathrm{Co}\right)$ which were simulated in the computer calculations. Distribution of a single $40 \mathrm{~K}$ plug loading in the heart was also compared with uniform source distributions in the lungs and inside the chest wall. In a later section of the report, the bias estimates obtained were used to develop recommendations for discrete source plugs in bioassay performance testing with in vivo phantoms. As a result, conclusions and recommendations are based on these estimates of bias. 


\section{COMPUTER CALCULATIONS}

Three radionuclides were simulated: ${ }^{144} \mathrm{Ce},{ }^{60} \mathrm{Co}$, and ${ }^{40} \mathrm{~K}$. The ${ }^{144} \mathrm{Ce}$ and ${ }^{60} \mathrm{Co}$ were simulated for loading in the phantom lungs, while the ${ }^{40} \mathrm{~K}$ was simulated for loading in the heart. This section describes the computer code used to calculate the radiation transport from the source to the detector, the computer modeling of the phantom, and the comparison of calculated dose rates at various detector locations.

COMPUTER CODE RNDSQR

The calculation of radiation transport from the radionuclide sources in the phantom through the solid material in the phantom and into the detector was performed by the computer code RNDSQR. This code is a modification of the computer code PERCS (Reece et al. 1983).

The PERCS and RNDSQR codes perform radiation transport and shielding calculations using the point-kernel integration technique. The point-kernel technique divides a region containing radionuclides into a number of small volumes (or kernels), and then calculates the dose to the reference point from the radiation emitted by each kernel, which is treated as a point source. The dose calculation also accounts for the attenuating effect of any energyabsorbing materials that lie between the point-kernel and the chosen reference points. The summation of the effects of all point-kernels in a region is equivalent to integration over the entire volume of the source region. The number of point-kernels chosen to represent a region has a direct effect on the quality of the integration, but a large number of point-kernels can cause long computation times. The point-kernel integration is therefore performed iteratively by choosing an initial number of point-kernels and then increasing their number until a comparison between two successive iterations meets a given convergence criterion.

The PERCS code has a number of desirable features including its ability to handle a large number of different source regions, its flexibility in the geometrical placement of source and shield regions, and innovative algorithms that rapidly perform the three-dimensional point-kernel integration 
calculations. PERCS was originally written to model contaminated pipes and tanks in a reactor and therefore has the inherent limitation that the source regions must be cylindrical. The PERCS code was modified to evaluate rectangular source regions. The modified version of PERCS was called RNDSQR, and this code was used to model the lung phantom with rectangular slabs for lungs.

PHANTOM MODEL

The arrangement of source and shield regions used by RNDSQR was designed to model the phantom regions that would be effective in containing radionuclides. The important regions in the phantom that were modeled include the chest wall, right lung, left lung, and heart.

The geometrical model used by this study is necessarily a rough approximation of the actual structure of the phantom components because the computer model uses only rectangular or cylindrical shapes for modeling doses. The dimensions of the modeled regions were chosen to approximate the same volumes as the organs that they model and to represent the average thickness of the organ for Reference Man (ICRP 1975). The positioning of the modeled regions was chosen such that the shielding effects of phantom components were closely approximated. Thus, an apparently rough approximation in the geometry can give a good estimate of detector response.

Because this study involved a comparison between uniform and point distributions of radionuclides, the approximation of using geometrical shapes for irregularly shaped organs applies equally to both distributions compared. Therefore, although the bias associated with the absolute calculated dose rates may be on the order of $25 \%$, the bias associated with the ratios of the dose rates was expected to be less than $5 \%$.

The heart was modeled as two rectangular solids, one on top of the other. The right lung was modeled as a single rectangular region, but the left lung was modeled as two regions, with one rotated to simulate the left lung curving behind the heart. The model regions and their dimensions are listed in Table 1, in which the model region volumes are compared to the volumes of organs in Reference Man (ICRP 1975). 
TABLE 1. Dimensions of Regions in the Phantom Model

\begin{tabular}{|c|c|c|c|c|c|}
\hline Region & $\begin{array}{c}\text { Thickness, } \\
\mathrm{cm}\end{array}$ & $\begin{array}{c}\text { Length, } \\
\mathrm{cm}\end{array}$ & $\begin{array}{c}\text { Height, } \\
\mathrm{cm}\end{array}$ & $\begin{array}{l}\text { Model } \\
\text { Volume, } \\
\mathrm{cm}^{3} \\
\end{array}$ & $\begin{array}{l}\text { Reference Man } \\
\text { Volume, } \mathrm{cm}^{3}\end{array}$ \\
\hline Right Lung & 6 & 18 & 17 & 1,836 & - \\
\hline $\begin{array}{l}\text { Left Lung } \\
\text { Upper } \\
\text { Lower }\end{array}$ & $\begin{array}{l}7 \\
7\end{array}$ & $\begin{array}{l}16 \\
16\end{array}$ & $\begin{array}{l}6 \\
7\end{array}$ & $\begin{array}{c}1,456 \\
- \\
-\end{array}$ & - \\
\hline Lungs (total) & & & & 3,292 & 3,333 \\
\hline $\begin{array}{l}\text { Heart } \\
\text { Upper } \\
\text { Lower }\end{array}$ & $\begin{array}{l}6 \\
8\end{array}$ & $\begin{array}{l}5 \\
9\end{array}$ & $\begin{array}{l}8 \\
8\end{array}$ & $\begin{array}{l}816 \\
240 \\
576\end{array}$ & $\begin{array}{c}783 \\
- \\
-\end{array}$ \\
\hline Chest Wall & 1.52 & 40 & 20 & - & - \\
\hline
\end{tabular}

The orientation of the regions is described by their positioning in a three-dimensional cartesian coordinate system. The coordinate system is oriented with the z-axis vertical (parallel to a line joining the phantom's waist to its head), the $y$-axis horizontal (parallel to a shoulder-to-shoulder line), and the $x$-axis anterior-posterior horizontal. The origin of the coordinate system was chosen to be on the inside of the chest wall. The region orientations are illustrated in Figure 1, looking down along the z-axis, and in Figure 2, looking along the $x$-axis at the front of the phantom, ignoring the chest wall.

The region orientations are precisely defined by the positioning coordinates listed in Table 2. The positioning scheme used here is used by RNDSOR to specify the locations, orientations, and size of rectangular regions. The base of a rectangular region must lie in an $x-y$ plane, but the vertical faces can be oriented at any angle from the $z$-axis (these faces are not required to lie in $x-z$ or $y-z$ planes). In the scheme used here, a line (called the "L-R line") is drawn from the center of the left face of the region to the center of its right face (because the regions may be oriented at an angle to the axes, the choice of left and right faces may be somewhat arbitrary). The $x$ - and $y$-coordinates of the ends of the L-R line are designated as $x_{1}, y_{1}$ and $x_{2}, y_{2}$. 


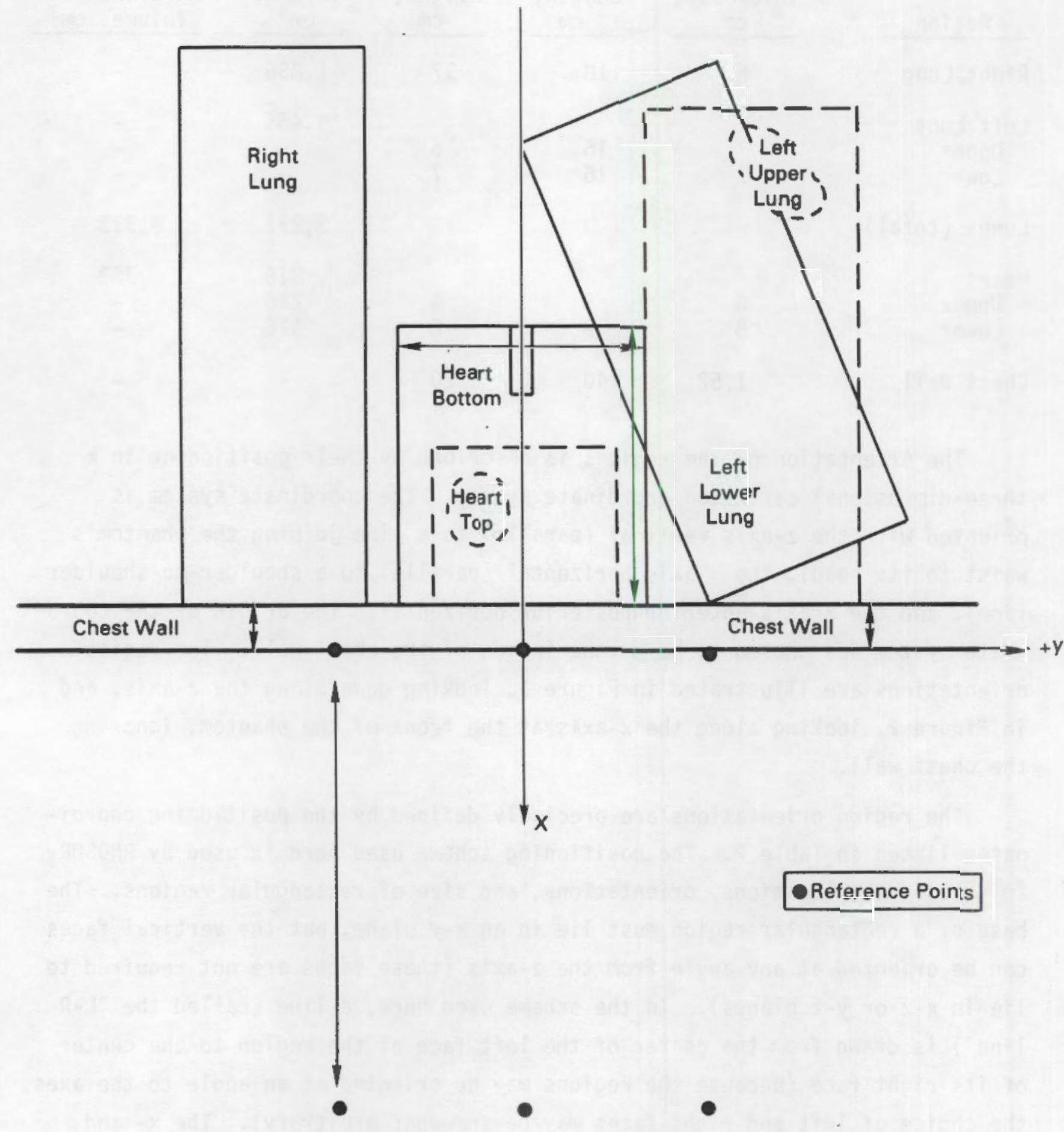

FIGURE 1. Orientation of Modeled Regions, $x-y$ Plane 


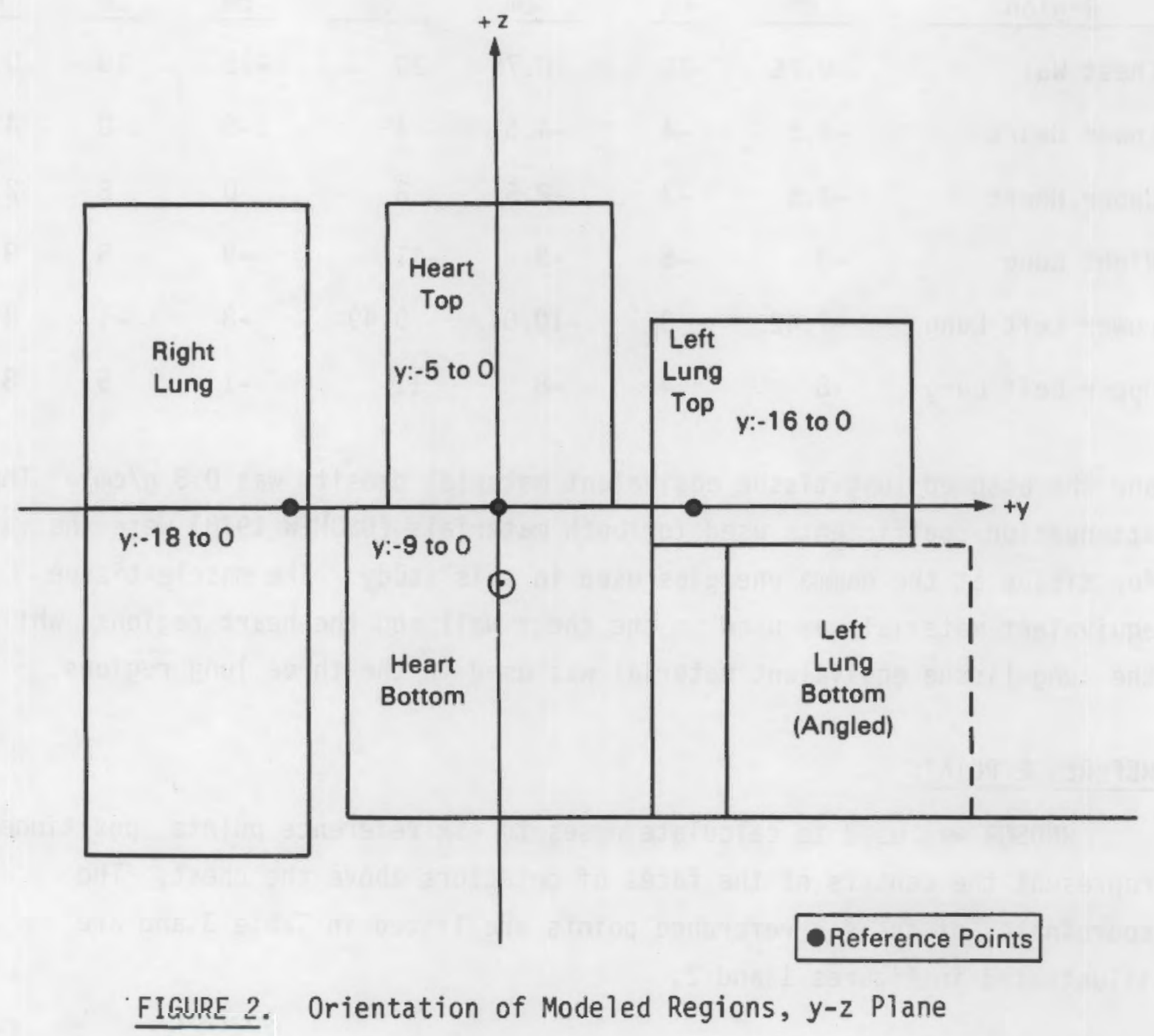

The $z$-coordinate of the base of the region is $z_{I}$, and the $z$-coordinate of the top face is $z_{h}$. The half-thickness $\left(t_{h}\right)$ is the distance from the L-R line to. either side face. Figure 3 illustrates these values for the lower heart region.

The regions in the phantom were assumed to be composed of either a muscle-tissue equivalent material or a lung-tissue equivalent material. The muscle-tissue equivalent material was assumed to have a density of $1.0 \mathrm{~g} / \mathrm{cm}^{3}$, 
TABLE 2. Positioning Coordinates for Lung Phantom Regions

\begin{tabular}{|c|c|c|c|c|c|c|c|}
\hline Region & $\begin{array}{l}x_{1}, \\
c m\end{array}$ & $\begin{array}{l}y_{1}, \\
c m \\
\end{array}$ & $\begin{array}{l}x_{2}, \\
c m \\
c m\end{array}$ & $\begin{array}{r}y_{2}, \\
\mathrm{~cm} \\
\end{array}$ & $\begin{array}{l}z_{1}, \\
\mathrm{~cm}\end{array}$ & $\begin{array}{l}z_{h}, \\
\mathrm{~cm}\end{array}$ & $\begin{array}{l}t_{h}, \\
\mathrm{~cm}\end{array}$ \\
\hline Chest Wall & 0.76 & -20 & 0.76 & 20 & -10 & 10 & 0.76 \\
\hline Lower Heart & -4.5 & -4 & -4.5 & 4 & -8 & 0 & 4.5 \\
\hline Upper Heart & -2.5 & -3 & -2.5 & 3 & 0 & 8 & 2.5 \\
\hline Right Lung & -9 & -5 & -9 & -11 & -9 & 8 & 9 \\
\hline Lower Left Lung & -7.42 & 3 & -10.04 & 9.49 & -8 & -1 & 8 \\
\hline Upper Left Lung & -8 & 4 & -8 & 11 & -1 & 5 & 8 \\
\hline
\end{tabular}

and the assumed lung-tissue equivalent material density was $0.3 \mathrm{~g} / \mathrm{cm}^{3}$. The attenuation coefficients used for both materials (USOHEW 1970) were the values for tissue at the gamma energies used in this study. The muscle-tissue equivalent material was used in the chest wall and the heart regions, while the lung-tissue equivalent material was used in the three lung regions.

REFERENCE POINTS

RNOSQR was used to calculate doses to six reference points, positioned to represent the centers of the faces of detectors above the chest. The coordinates of the six reference points are listed in Table 3 and are illustrated in Figures 1 and 2.

\section{SOURCE PLUGS}

For the nonuniform loading of radionuclides in the phantom, the nuclides were assumed to be contained in plugs composed of muscle-tissue equivalent material. In one case, one plug was located in the bottom heart region; in the other cases the plugs were located in the lung regions. All plugs were assumed to be $0.8-\mathrm{cm}-\mathrm{dia}, 2.8-\mathrm{cm}-1$ ong cylinders.

The heart plug was located at the back of the lower heart region, with the axis of the plug cylinder extending from the point with $x-, y-$, and $z$-coordinates of $(-6.2,0,-2)$ to $(-9,0,-2)$. The plug was assumed to contain 


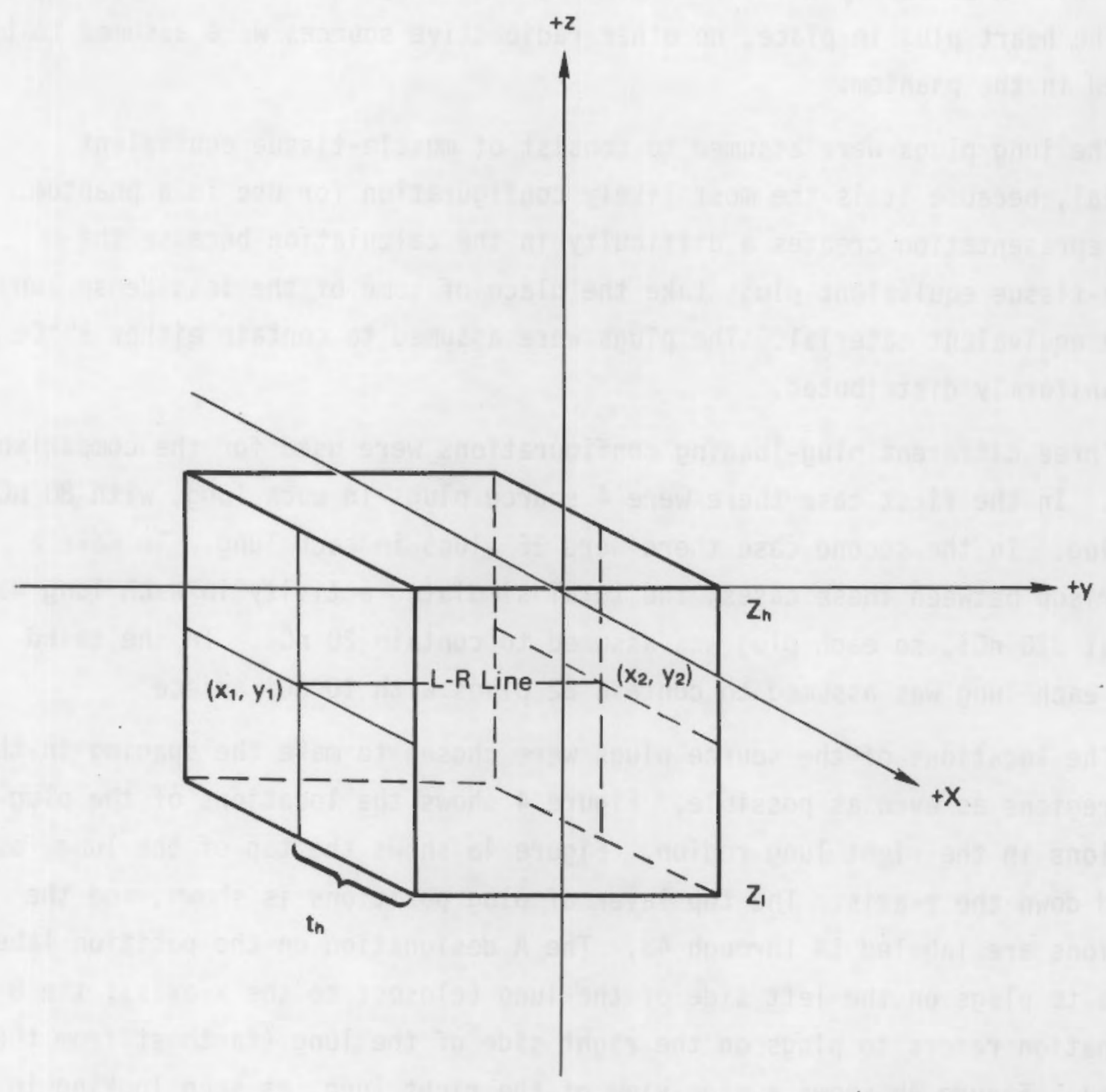

FIGURE 3. Orientation of the Modeled Lower Heart Region

TABLE 3. Reference Point Coordinates

ID

ID

$\begin{array}{rr}1 & \mathrm{x} \\ & 1.6 \\ 3 & 1.6 \\ 4 & 1.6 \\ 5 & 16.6 \\ 6 & 16.6 \\ & 16.6\end{array}$

$\begin{array}{rrr}\frac{y}{6.0} & & z \\ 0.0 & & 0.0 \\ -6.0 & & 0.0 \\ 6.0 & & 0.0 \\ 0.0 & & 0.0 \\ -6.0 & & 0.0\end{array}$

Comments

At chest wall, over left lung

At chest wall, center of chest

At chest wall, over right lung

$15 \mathrm{~cm}$ from chest, over left lung

$15 \mathrm{~cm}$ from chest, center of chest

$15 \mathrm{~cm}$ from chest, over right lung 
$80 \mathrm{nCi}$ of $40 \mathrm{~K}$ uniformly distributed throughout the plug. In the calculation with the heart plug in place, no other radioactive sources were assumed to be located in the phantom.

The lung plugs were assumed to consist of muscle-tissue equivalent material, because it is the most likely configuration for use in a phantom. This representation creates a difficulty in the calculation because the muscle-tissue equivalent plugs take the place of some of the less dense lungtissue equivalent material. The plugs were assumed to contain either ${ }^{144} \mathrm{Ce}$ or ${ }^{60} \mathrm{Co}$ uniformly distributed.

Three different plug-loading configurations were used for the comparison tests. In the first case there were 4 source plugs in each lung, with $80 \mathrm{nCi}$ per plug. In the second case there were 16 plugs in each lung. To make a comparison between these cases, the total simulated activity in each lung was kept at $320 \mathrm{nCi}$, so each plug was assumed to contain $20 \mathrm{nCi}$. In the third case, each lung was assumed to contain 32 plugs with $10 \mathrm{nCi}$ apiece.

The locations of the source plugs were chosen to make the spacing in the lung regions as even as possible. Figure 4 shows the locations of the plug positions in the right lung region. Figure $4 a$ shows the top of the lung, as viewed down the z-axis. The top layer of plug positions is shown, and the positions are labeled $1 A$ through $4 B$. The $A$ designation on the position label refers to plugs on the left side of the lung (closest to the $x$-axis); the $B$ designation refers to plugs on the right side of the lung (farthest from the $x$-axis). Figure $4 b$ shows a side view of the right lung, as seen looking in the $+y$ direction. Plug locations 1 through 16 are shown for an $x-z$ plane.

Figure 5 illustrates the locations of the source plugs in the left lung regions. Figure $5 \mathrm{a}$ shows the locations of plugs in the top layer of the upper left lung region; these plug locations are labeled $1 \mathrm{~A}$ through $4 \mathrm{~B}$. Figure $5 \mathrm{~b}$ shows plug locations $9 \mathrm{~A}$ through 12B, from the top layer of the lower left lung region. Figure $5 c$ is a side view of the two left lung regions, with the lower lung rotated so that all of the plug axes would be parallel. This orientation gives a clearer view of the locations of the plugs with respect to the left lung region boundaries. The locations of plugs 1 through 16 are illustrated. 

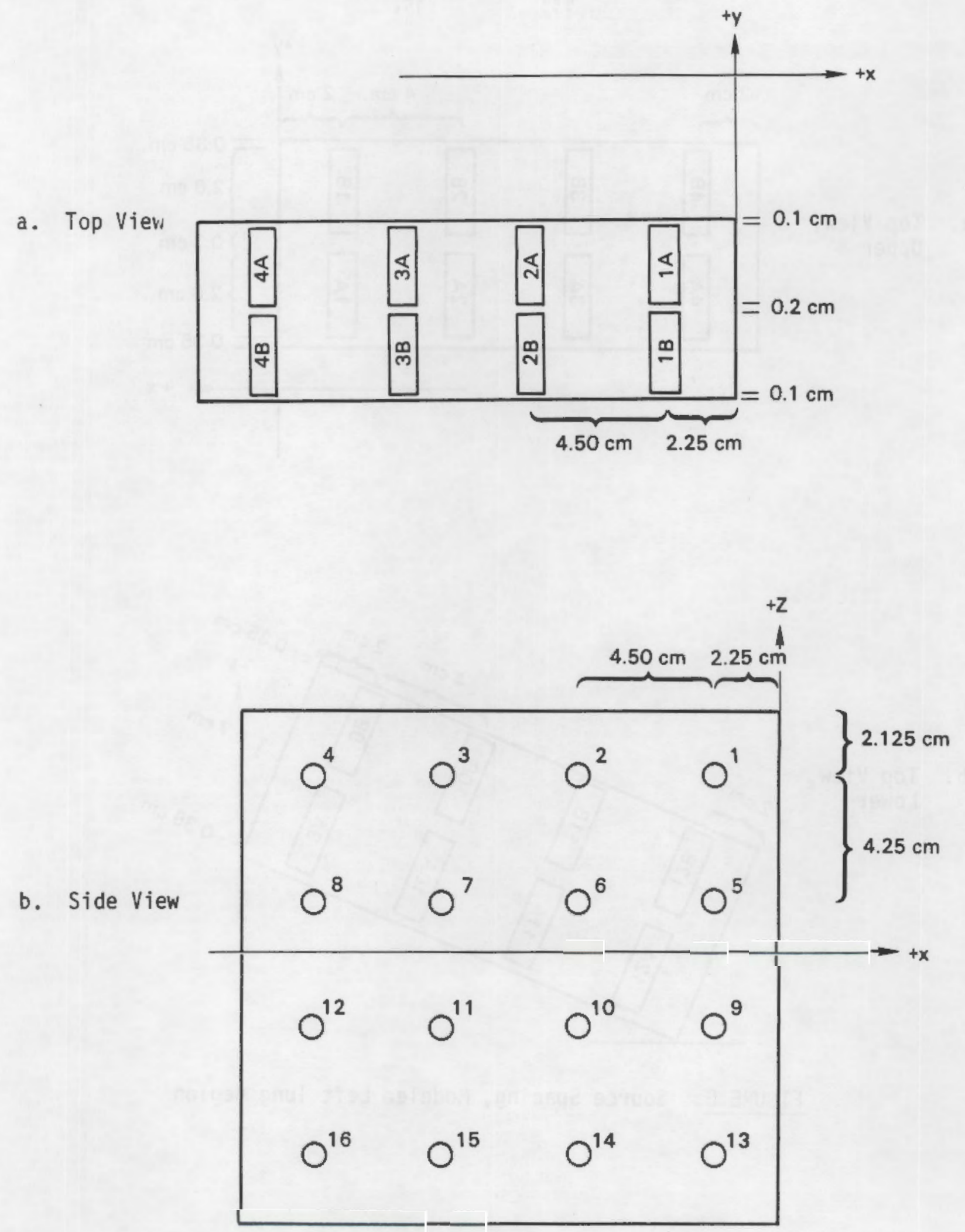

FIGURE 4. Source Spacing, Modeled Right Lung Region 


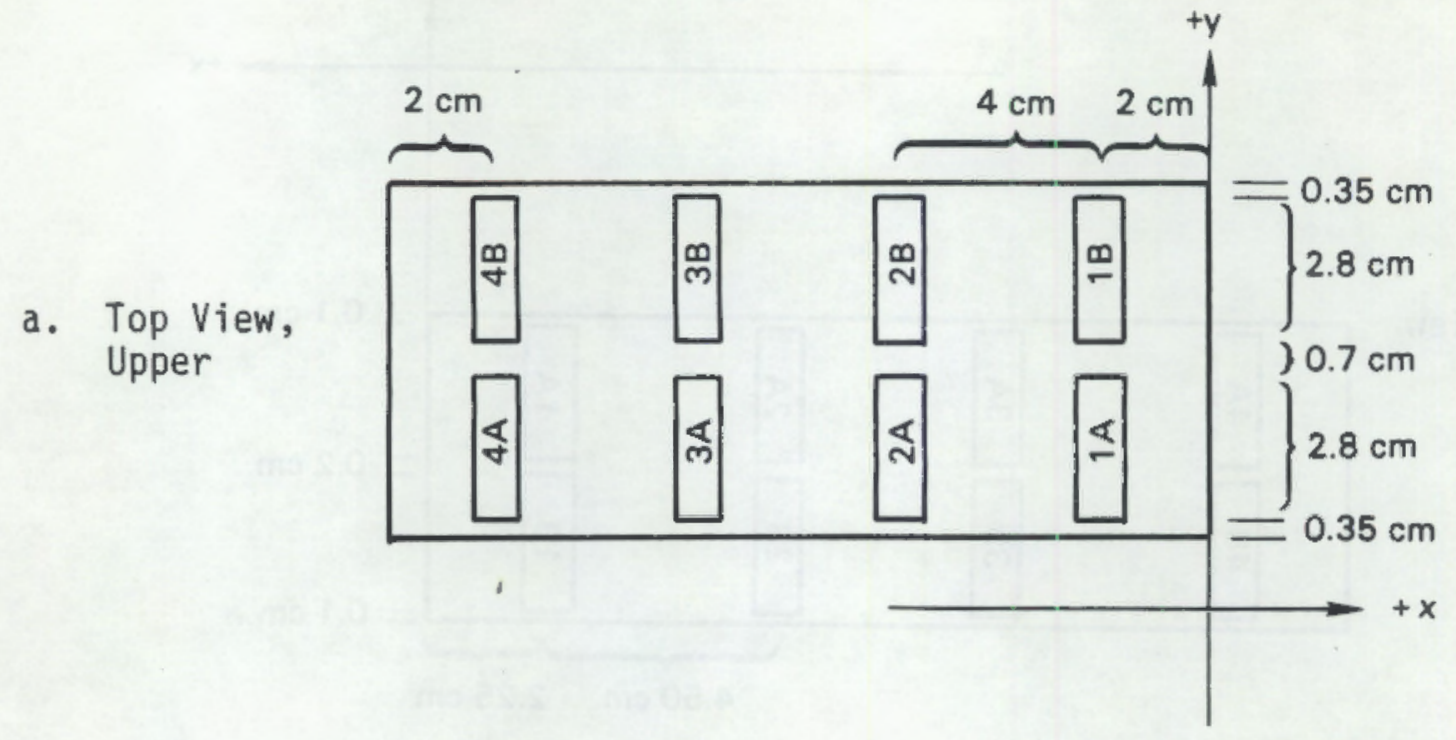

b. Top View, Lower

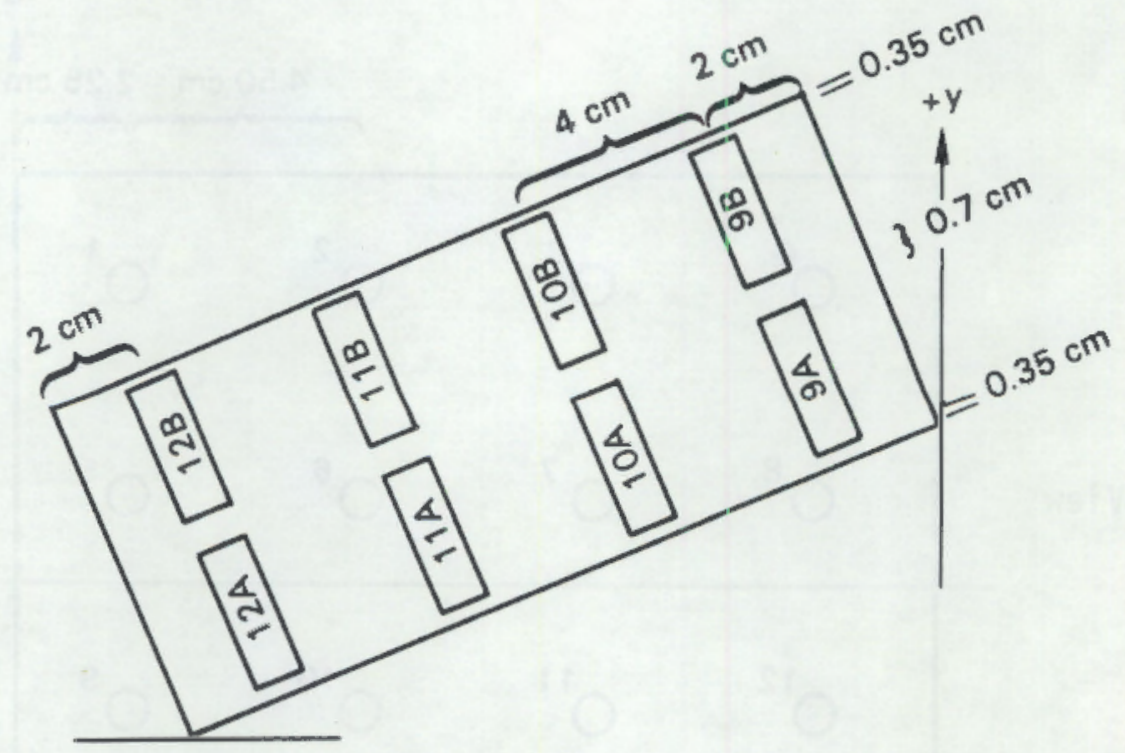

FIGURE 5. Source Spacing, Modeled Left lung Region 


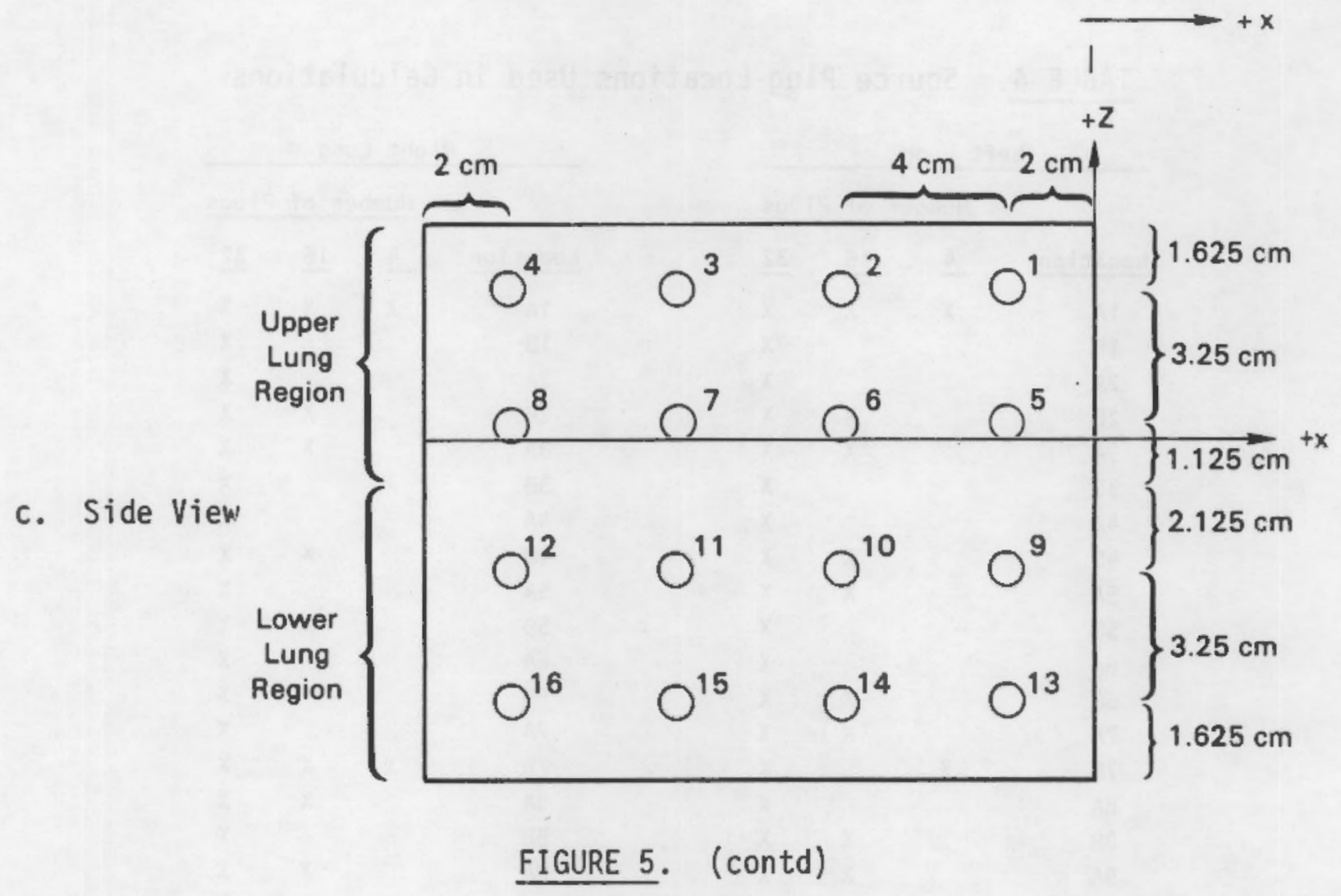


Table 4 shows which source plugs were used for each of the three configurations $(4,16$, or 32 source plugs).

TABLE 4. Source Plug Locations Used in Calculations

Left Lung

\begin{tabular}{|c|c|c|c|}
\hline & Number & of & Plugs \\
\hline Location & 4 & $\underline{16}$ & $\underline{32}$ \\
\hline $1 \mathrm{~A}$ & $x$ & $x$ & $x$ \\
\hline $1 \mathrm{~B}$ & & & $x$ \\
\hline $2 A$ & & & $x$ \\
\hline 28 & & $x$ & $x$ \\
\hline $3 A$ & & $x$ & $x$ \\
\hline 38 & & & $x$ \\
\hline $4 \mathrm{~A}$ & & & $x$ \\
\hline $4 B$ & & $x$ & $x$ \\
\hline $5 A$ & & $x$ & $x$ \\
\hline $5 B$ & & & $x$ \\
\hline $6 A$ & & & $x$ \\
\hline $6 B$ & & $x$ & $x$ \\
\hline $7 A$ & & $x$ & $x$ \\
\hline 78 & $x$ & & $x$ \\
\hline $8 A$ & & & $x$ \\
\hline $8 B$ & & $x$ & $x$ \\
\hline $9 A$ & & $x$ & $x$ \\
\hline 98 & & & $x$ \\
\hline $10 \mathrm{~A}$ & $x$ & & $x$ \\
\hline $10 \mathrm{~B}$ & & $x$ & $x$ \\
\hline $11 \mathrm{~A}$ & & $x$ & $x$ \\
\hline $11 \mathrm{~B}$ & & & $x$ \\
\hline $12 \mathrm{~A}$ & & & $x$ \\
\hline $12 B$ & & $x$ & $x$ \\
\hline $13 A$ & • & $x$ & $x$ \\
\hline 138 & & & $x$ \\
\hline $14 \mathrm{~A}$ & & & $x$ \\
\hline $14 \mathrm{~B}$ & & $x$ & $x$ \\
\hline $15 A$ & & $x$ & $x$ \\
\hline $15 B$ & & & $x$ \\
\hline $16 \mathrm{~A}$ & & & $x$ \\
\hline $16 \mathrm{~B}$ & $x$ & $x$ & $x$ \\
\hline
\end{tabular}

\section{Right lung}

\begin{tabular}{|c|c|c|c|}
\hline \multirow[b]{2}{*}{ Location } & \multicolumn{2}{|c|}{ Number of } & \multirow{2}{*}{$\begin{array}{r}\text { Plugs } \\
\underline{32}\end{array}$} \\
\hline & 4 & 16 & \\
\hline $1 \mathrm{~A}$ & $x$ & $x$ & $x$ \\
\hline $1 \mathrm{~B}$ & & & $x$ \\
\hline $2 A$ & & & $x$ \\
\hline $2 B$ & & $x$ & $x$ \\
\hline $3 A$ & & $x$ & $x$ \\
\hline $3 B$ & & & $x$ \\
\hline $4 A$ & & & $x$ \\
\hline 4B & & $x$ & $x$ \\
\hline $5 A$ & & & $x$ \\
\hline $5 B$ & & $x$ & $x$ \\
\hline $6 A$ & & $x$ & $x$ \\
\hline $6 \mathrm{~B}$ & & & $x$ \\
\hline $7 A$ & & & $x$ \\
\hline 78 & $x$ & $x$ & $x$ \\
\hline $8 A$ & & $x$ & $x$ \\
\hline $8 B$ & & & $x$ \\
\hline $9 A$ & & $x$ & $x$ \\
\hline $9 \mathrm{~B}$ & & & $x$ \\
\hline $10 \mathrm{~A}$ & $\mathrm{x}$ & & $x$ \\
\hline $10 \mathrm{~B}$ & & $x$ & $x$ \\
\hline $11 \mathrm{~A}$ & & $x$ & $x$ \\
\hline 118 & & & $x$ \\
\hline $12 A$ & & & $x$ \\
\hline $12 B$ & & $x$ & $x$ \\
\hline $13 \mathrm{~A}$ & & & $x$ \\
\hline 138 & & $x$ & $x$ \\
\hline $14 \mathrm{~A}$ & & $x$ & $x$ \\
\hline $14 B$ & & & $x$ \\
\hline $15 A$ & & & $x$ \\
\hline $15 B$ & & $x$ & $x$ \\
\hline $16 \mathrm{~A}$ & & $x$ & $x$ \\
\hline $16 \mathrm{~B}$ & $x$ & & $x$ \\
\hline
\end{tabular}


$\underline{\text { RESULTS }}$

Dose rates at six reference points were calculated for the following three simulated nuclide loadings: ${ }^{40} \mathrm{~K},{ }^{144} \mathrm{Ce}$, and ${ }^{60} \mathrm{Co}$. The comparisons are shown as relative biases, defined as the differences between the compared dose rates divided by the uniform in-lung dose rates (the relative bias would be zero for perfect agreement).

POTASSIUM-40

Three different radionuclide loadings were used to calculate dose rates resulting from ${ }^{40} \mathrm{~K}$ distributed in the phantom:

- $80 \mathrm{nCi}$ in a plug in the heart

- $80 \mathrm{nCi}$ distributed uniformly inside the chest wal1

- $80 \mathrm{nci}$ distributed uniformly in the Tungs.

The calculated dose rates at each of the six detectors for the three different nuclide loadings are shown in Table 5.

Table 6 shows a comparison of the dose rates calculated using the configuration of a source plug in the heart to the dose rates calculated using a uniform distribution of ${ }^{40} \mathrm{~K}$ in the lungs. A comparison of the dose rates using the distribution of ${ }^{40} \mathrm{~K}$ inside the chest wall to the dose rates using a uniform distribution in the lungs is also shown in Table 6.

TABLE 5. Calculated Dose Rates from ${ }^{40} \mathrm{~K}$

\begin{tabular}{|c|c|c|c|}
\hline \multirow{2}{*}{ Reference Points } & \multicolumn{3}{|c|}{ Calculated Dose Rates, mrad/h } \\
\hline & $\begin{array}{l}\text { PTug } \\
\text { in Heart }\end{array}$ & $\begin{array}{c}\text { Inside } \\
\text { Chest Wall } \\
\end{array}$ & $\begin{array}{l}\text { Uniform } \\
\text { in Lungs }\end{array}$ \\
\hline At chest wall, over left lung & $4.79 \times 10^{-4}$ & $1.72 \times 10^{-3}$ & $5.04 \times 10^{-14}$ \\
\hline At chest wall, center & $6.82 \times 10^{-4}$ & $1.78 \times 10^{-3}$ & $4.37 \times 10^{-4}$ \\
\hline At chest wa 11 , over right lung & $4.79 \times 10^{-4}$ & $1.67 \times 10^{-3}$ & $5.55 \times 10^{-4}$ \\
\hline $15 \mathrm{~cm}$ from chest, over left lung & $9.47 \times 10^{-5}$ & $1.79 \times 10^{-4}$ & $9.10 \times 10^{-5}$ \\
\hline $15 \mathrm{~cm}$ from chest, center & $1.01 \times 10^{-5}$ & $1.90 \times 10^{-4}$ & $9.76 \times 10^{-5}$ \\
\hline $15 \mathrm{~cm}$ from chest, over right lung & $9.47 \times 10^{-5}$ & $1.79 \times 10^{-4}$ & $9.56 \times 10^{-5}$ \\
\hline
\end{tabular}


TABLE 6. Comparison of Dose Rates from ${ }^{40 \mathrm{~K}}$

\section{Reference Point}

At chest wall, over left lung

At chest wall, center

At chest wall, over right lung

$15 \mathrm{~cm}$ from chest, over left lung

15. $\mathrm{cm}$ from chest, center

$15 \mathrm{~cm}$ from chest, over right lung

\begin{tabular}{lc}
\multicolumn{2}{c}{ Relative Bias } \\
\hline Plug & Inside \\
in Heart & Chest Wall \\
\hline
\end{tabular}

$-0.05$

$+2.41$

$-0.56$

$+3.07$

$-0.14$

$+2.01$

$+0.04$

$+0.97$

$+0.04$

$+0.95$

$-0.01$

$+0.87$

\section{CERIUM-144}

Four different radionuclide distributions in the phantom were used to calculate dose rates at the six detector locations:

- $320 \mathrm{nCi}$ uniformly distributed in each lung

- 32 plugs (10 nci per plug) in each lung

- 16 plugs (20 nCi per plug) in each lung

- 4 plugs (80 nCi per plug) in each lung.

Table 7 lists the results of these calculations.

The comparison of calculated dose rates from different plug loadings to the uniform distribution of $144 \mathrm{Ce}$ in the lungs is shown in Table 8 . The values listed in Table 8 are the ratios of the relative biases of the dose rates to the dose rates at the same location due to a uniform distribution in the lungs.

\section{TABLE 7. Calculated Dose Rates from $144 \mathrm{Ce}$}

\begin{tabular}{|c|c|c|c|c|}
\hline Reference Points & $\begin{array}{l}\text { Uniform } \\
\text { in Lungs }\end{array}$ & $\begin{array}{c}\text { culated Do } \\
32 \text { Source } \\
\text { Plugs }\end{array}$ & $\begin{array}{l}\text { tes, mrad } \\
16 \text { Source } \\
\text { Plugs } \\
\end{array}$ & $\begin{array}{l}4 \text { Source } \\
\text { Plugs }\end{array}$ \\
\hline $\begin{array}{l}\text { At chest wall, } \\
\text { over left lung }\end{array}$ & 0.00159 & 0.00156 & 0.00174 & 0.00176 \\
\hline At chest wall, center & 0.00127 & 0.00113 & 0.00119 & 0.00133 \\
\hline
\end{tabular}




\section{TABLE 7.• (contd)}

\begin{tabular}{llccc}
\multicolumn{4}{c}{ Calculated Dose Rates, mrad/h } \\
\cline { 1 - 2 } $\begin{array}{l}\text { Reference Points } \\
\begin{array}{l}\text { At chest wal1, } \\
\text { over right lung }\end{array}\end{array}$ & $\begin{array}{l}\text { Uniform } \\
\text { in Lungs }\end{array}$ & $\begin{array}{c}\text { 32 Source } \\
\text { Plugs }\end{array}$ & $\begin{array}{c}\text { 16 Source } \\
\text { Plugs }\end{array}$ & $\begin{array}{c}4 \text { Source } \\
\text { Plugs }\end{array}$ \\
$\begin{array}{l}15 \mathrm{~cm} \text { from chest, } \\
\text { over left lung }\end{array}$ & 0.00151 & 0.00138 & 0.00138 & 0.00126 \\
$\begin{array}{l}15 \mathrm{~cm} \text { from chest, } \\
\text { center }\end{array}$ & 0.000288 & 0.000284 & 0.000286 & 0.000293 \\
$\begin{array}{l}15 \mathrm{~cm} \text { from chest, } \\
\text { over right lung }\end{array}$ & 0.000275 & 0.000270 & 0.000272 & 0.000275
\end{tabular}

TABLE 8. Relative Bias in Calculated Dose Rates from ${ }^{144} \mathrm{Ce}$

\begin{tabular}{|c|c|c|c|}
\hline Reference Points & $\begin{array}{c}\text { Relat } \\
32 \text { Source } \\
\text { Plugs } \\
\end{array}$ & $\begin{array}{l}\text { in Calculat } \\
16 \text { Source } \\
\text { Plugs } \\
\end{array}$ & $\begin{array}{l}\text { ates } \\
4 \text { Source } \\
\text { Plugs } \\
\end{array}$ \\
\hline $\begin{array}{l}\text { At chest wall, } \\
\text { over left lung }\end{array}$ & -0.02 & +0.09 & +0.11 \\
\hline At chest wall, center & -0.11 & -0.06 & +0.05 \\
\hline $\begin{array}{l}\text { At chest wall, } \\
\text { over right lung }\end{array}$ & -0.09 & -0.09 & -0.17 \\
\hline $\begin{array}{l}15 \mathrm{~cm} \text { from chest, } \\
\text { over left lung }\end{array}$ & 0.00 & +0.01 & +0.04 \\
\hline $\begin{array}{l}15 \mathrm{~cm} \text { from chest, } \\
\text { center }\end{array}$ & -0.01 & -0.01 & +0.02 \\
\hline $\begin{array}{l}15 \mathrm{~cm} \text { from chest, } \\
\text { over right lung }\end{array}$ & -0.02 & -0.01 & 0.00 \\
\hline
\end{tabular}

$\underline{\text { COBALT }-60}$

For ${ }^{60} \mathrm{Co}$, four loadings were used to calculate the dose rates at the following six detector locations:

- $320 \mathrm{nCi}$ uniformly distributed in each lung

- 32 plugs (10 nCi per plug) in each lung 
- 16 plugs (20 nCi per plug) in each lung

- 4 plugs (80 nCi per plug) in each lung.

The results of these calculations are listed in Table 9. The relative bias in the calculated dose rates compared to the dose rates from a uniform distribution of ${ }^{60} \mathrm{Co}$ in the lungs is shown in Table 10.

TABLE 9. Calculated 0ose Rates from ${ }^{60} \mathrm{Co}$

\begin{tabular}{|c|c|c|c|c|}
\hline Reference Points & $\begin{array}{l}\text { Uniform } \\
\text { in Lungs }\end{array}$ & $\begin{array}{c}\text { Calculated Dose } \\
32 \text { Source } \\
\text { Plugs }\end{array}$ & $\begin{array}{c}\text { Rates, mrad/h } \\
16 \text { Source } \\
\text { Plugs } \\
\end{array}$ & $\begin{array}{l}4 \text { Source } \\
\text { Plugs }\end{array}$ \\
\hline $\begin{array}{l}\text { At chest wall, } \\
\text { over left lung }\end{array}$ & 0.0735 & 0.0725 & 0.0715 & 0.0814 \\
\hline At chest wal1, center & 0.0598 & 0.0536 & 0.0535 & 0.0628 \\
\hline $\begin{array}{l}\text { At chest wall, } \\
\text { over right lung }\end{array}$ & 0.0698 & 0.0644 & 0.0638 & 0.0590 \\
\hline $\begin{array}{l}15 \mathrm{~cm} \text { from chest, } \\
\text { over left lung }\end{array}$ & 0.0125 & 0.0125 & 0.0125 & 0.0129 \\
\hline $\begin{array}{l}15 \mathrm{~cm} \text { from chest, } \\
\text { center }\end{array}$ & 0.0132 & 0.0130 & 0.0130 & 0.0134 \\
\hline $\begin{array}{l}15 \mathrm{~cm} \text { from chest, } \\
\text { over right lung }\end{array}$ & 0.0127 & 0.0125 & 0.0125 & 0.0127 \\
\hline
\end{tabular}


TABLE 10. Relative Bias in Calculated Dose Rates from ${ }^{60} \mathrm{Co}$

\begin{tabular}{|c|c|c|c|}
\hline Reference Points & $\begin{array}{l}\text { Relat } \\
32 \text { Source } \\
\text { Plugs } \\
\end{array}$ & $\begin{array}{l}\text { in Calculat } \\
16 \text { Source } \\
\text { Plugs } \\
\end{array}$ & $\begin{array}{l}\text { Rates } \\
4 \text { Source } \\
\text { Plugs }\end{array}$ \\
\hline $\begin{array}{l}\text { At chest wall, } \\
\text { over left lung }\end{array}$ & -0.01 & -0.03 & +0.11 \\
\hline At chest wall, center & -0.10 & -0.11 & +0.05 \\
\hline $\begin{array}{l}\text { At chest wall, } \\
\text { over right lung }\end{array}$ & -0.03 & -0.09 & -0.15 \\
\hline $\begin{array}{l}15 \mathrm{~cm} \text { from chest, } \\
\text { over left lung }\end{array}$ & 0.00 & 0.00 & +0.03 \\
\hline $\begin{array}{l}15 \mathrm{~cm} \text { from chest, } \\
\text { center }\end{array}$ & -0.02 & -0.02 & +0.02 \\
\hline $\begin{array}{l}15 \mathrm{~cm} \text { from chest, } \\
\text { over right lung }\end{array}$ & -0.02 & -0.02 & 0.00 \\
\hline
\end{tabular}




\section{CONCLUSIONS AND RECOMMENDATIONS}

The simulations described in this report indicate that a single plug containing ${ }^{40} \mathrm{~K}$ located in the back of the heart is a good approximation to a uniform distribution of $40 \mathrm{~K}$ throughout the lungs for five of the six reference points tested. However, a single plug in the heart would lead to a high bias when the dose rate at the center of the chest surface is compared to a uniform distribution of $40 \mathrm{~K}$. A detector placed in this position would be closer to the source with less attenuating material intervening than for the other reference points. Thus, the plug gives a dose rate at this point with a $56 \%$ positive bias. For other reference points, the masses of attenuating materiai for the point and uniform distributions are similar and the biases are less than $5 \%$ (except at the chest surface over the right lung with a $14 \%$ negative bias).

Loading the $40 \mathrm{~K}$ in a uniform layer inside the chest wall would not be a. good approximation to a uniform distribution in the lungs because most of the radionuclide would be close to the reference point, and the only absorbing material would be the chest wall. This distribution, therefore, gives dose rates to a detector at the chest wall that would be three to four times higher than those measured with a uniform source distribution in the lungs.

The comparison calculations for ${ }^{60} \mathrm{Co}$ were very similar to the calculations for $144 \mathrm{Ce}$. Each of the three plug loadings resulted in a very gond approximation to the uniform distribution for reference points $15 \mathrm{~cm}$ away from the chest wall. For these reference points, relative biases were less than $4 \%$.

For reference points at the chest wall, the configuration of four source plugs per lung produced less desirable biases than the other two loadings. The estimated dose rate to a detector placed over the left lung would have an $11 \%$ positive bias for both nuclides. Over the right lung, negative biases of $17 \%$ and $15 \%$ for $1{ }^{44} \mathrm{Ce}$ and $60 \mathrm{Co}$, respectively, were estimated. At the center of the chest wall, a positive $5 \%$ bias was estimated for both nuclides. These values are still in reasonable agreement with those of other loadings, but a choice of four different plug locations may have given a poorer comparison. 
Calculations showed that there was not much difference in expected bias of calculated dose rates at the chest wall between loadings of 16 plugs per lung and 32 plugs per lung. The cases with 32 plugs per lung gave slightly lower biases than cases with 16 , but 011 estimated biases were small relative to other biases of significance in the bioassay process. In all cases the deviation from the uniform distribution dose rate was less than $12 \%$, with most relative biases less than $10 \%$.

If a bias of $5 \%$ or less is considered acceptable, no plug loading configuration of ${ }^{144} \mathrm{Ce}$ or ${ }^{60} \mathrm{Co}$ provided a good approximation to a uniform source distribution in the lungs for use with counting systems where the detector is positioned near the chest surface. Nor would a single source plug in the heart adequately simulate the uniform distribution of ${ }^{40} \mathrm{~K}$ in the lungs. Plug loading would be an acceptable al ternative to uniform source distributions only when the measurement system incorporates a detector that is $15 \mathrm{~cm}$ or more from the chest surface. Because of this limitation, plug source loading of phantoms used for bioassay laboratory performance testing is not recommended. 


\section{REFERENCES}

International Cormission on Radiological Protection (ICRP). 1975. Report of the Task Group on Reference Man. ICRP Publication 23, Pergamon Press, Oxford, England.

Reece, W.D., R.T. Hadley, R. Harty, J. Glass, J.E. Tanner and L.F. Munson. 1983. Personnel Exposure from Right Cylindrical Sources (PERCS). NUREG/CR-3573, PNL-4923, U.S. NucTear ReguTatory Comilission, Washington, D.C.

U.S. Department of Health, Education, and Welfare, Public Health Services (USDHEW). 1970. Radiological Health Handbook. U.S. Government Printing Office, Washington, D.C. 
. 


\section{DISTRIBUTION}

No. of

Copies

OFFS ITE

30 DOE Technical Information Center

DOE Headquarters

R. W. Barber, Director Office of Nuclear Safety U.S. Department of Energy Washington, DC 20545

R. P. Berube, Acting Director Assistant Secretary for Environment, Safety, and Health U.S. Department of Energy Washington, DC 20545

D. F. Bunch, Acting Deputy Assistant Secretary for Safety, Health, and Quality Assurance

U.S. Department of Energy Washington, DC 20545

L. J. Dea\}

U.S Department of Energy

Washington, DC 20545

N. Goldenberg, Acting Director Quality Assurance

U.S. Department of Energy

Washington, DC 20545

Bette L. Murphy

Office of Nuclear Safety U.S Department of Energy

Washington, DC 20545

D. R. Nelson

Office of Nuclear Safety

U.S. Department of Energy

Washington, DC 20545

G. K. Oertel

U.S. Department of Energy

Washington, DC 20545
No. of

Copies

R. J. Stern, Director

Office of Environmental Guidance

U.S. Department of Energy

Washington, DC 20545

25 E. J. Vallario, Acting Director Radiological Controls Division U.S. Department of Energy Washington, DC 20545

M. Walker Assistant Secretary for Enviromment, Safety, and Health U.S. Department of Energy Washington, DC 20545

DOE Albuquerque Operations Office

R. E. Alexander

Pantex Plant

Mason \& Hanger--Silas Mason Co., Inc.

P.0. Box 30020

Amaril10, TX 79177

W. D. Burnett

DOE Sandia National Laboratories

Mail Code 3312, Bidg. 8619

P.0. Box 2800

Albuquerque, NM 87115

G. W. Campbe11

Rockwe 11 International

Rocky Flats Plant

P.0. Box 464

Golden, CO 80401

R. Falk

Rockwell Internationa 1

Rocky Flats Plant

P.0. Box 464

Golden, CO 80401 
No. of

Copies

C. E. Garcia

U.S. Department of Energy

Albuquerque Operations Office

P.0. Box 5400

Albuquerque, NM 87115

D. Krenz

U.S. Department of Energy

ATbuquerque Operations Office P.0. Box 5400

Albuquerque, NM 87155

H. E. Meyer

Mound Laboratory

Monsanto Research Corporation

Miamisburg, OH 45342

W. Moss

Los Alamos National Laboratory

P.0. Box 1663

Los Alamos, NM 87545

P. M. Ramey

U.S. Department of Energy

A]buquerque Operations Office

P.0. Box 5400

Albuquerque, NM 87115

R. G. Stafford

Los Alamos National Laboratory

P.0. Box 1663

Los Alamos, NM 87545

J. G. Themel is

U.S. Department of Energy

Albuquerque Operations Office

P.0. Box 5400

A7buquerque, NM 87115

J. J. Thompson

Lovelace Biomedical \& Environmental

Research Laboratories

P.0. Box 5890

Albuquerque, NM 87115
No. of

Copies

A. M. Valentine

Los Alamos National Laboratory

P.0. Box 1663

Los ATamos, NM 87545

M. G. White

U.S. Department of Energy

P.0. Box 5400

Albuquerque, NM 87115

R. E. Yoder

Rockwell International

Rocky Flats Plant

P.0. Box 888

Golden, CO 80402

DOE Chicago Operations Office

D. L. Bray

U.S. Department of Energy

9800 S. Cass Ave.

Argonne, IL 60439

L. V. Coutson

Fermi National Accelerator Laboratory

P.0. Box 500

Batavia, IL 60510

E. H. Dolecek

Argonne National Laboratory

9700 S. Cass Ave., Bldg. 201

Argonne, IL 60439

C. B. Meinhold

Brookhaven National Laboratory

Associated Universities, Inc.

Upton, NY 11973

R. Moser

U.S. Department of Energy

Chicago Operations Office

9800 South Cass Avenue

Argonne, IL 60439 
No. of

Copies

D. P. O'Neil

Argonne National Laboratory

9800 South Cass Avenue

Argonne, IL 60439

DOE Idaho Operations Office

J. H. Barry

U.S. Department of Energy

Idaho Operations Office

785 DOE Place

Idaho Falls, ID 83402

T. F. Gesell

U.S. Department of Energy

Idaho Operations office

550 2nd Street

Idaho Falls, ID 83401

B. L. Rich

EG\&G Idaho

P.0. Box 1625

Idaho Falls, ID 83401

A. N. Tschaeche

WINCO

$M / S$ CPP -630

P.0. Box 4000

Idaho Falls, ID 83403

DOE Naval Reactors Office

T. L. Collins

U.S. Department of Energy

Knolls Atomic Power Laboratory

P.0. Box 1072

Schenectady, NY 12301

A. C. Davis

Westinghouse Electric Corporation

Bettis Atomic Power Lab. (DOE)

P.0. Box 79

West Mifflin, PA 15122

C. K. Gaddis

Pittsburgh Naval Reactors Office

P.0. Box 109

W. Mifflin, PA 15122
No. of

Copies

DOE Nevada Operations Office

A. E. Bicker

Reynolds Electrical \& Engineering Co., Inc.

P.0. Box 14400

Las Vegas, NV 89114

B. W. Church

U.S. Department of Energy

Nevada Operations Office

P.0. Box 14100

Las Vegas, NV 89114

S. R. Elliot

U.S. Department of Energy

Nevada Operations Office

P.0. Box 14100

Las Vegas, NV 89114

DOE Oak Ridge Operations Office

R. C. Baker

Paducah Gaseous Diffusion Plant

P.0. Box 1410

Paducah, KY 42001

W. F. Furth

Martin Marietta Energy Systems

P.0. Box $X$

Oak Ridge, TN 37831

R. E. Halliburton

Oak Ridge National Laboratory

P.0. Box $X$

Oak Ridge, TN 38730

S. L. Hinnefeld

Westinghouse Materiats Co. of Ohio

P.0. Box 398704

Cincinnati, $\mathrm{OH} \quad 45239$

D. B. Howard

U.S. Department of Energy

0ak Ridge Operations Office

P.0. Box E

Oak Ridge, TN 37831 
No. of

Copies

T. M. Jelinek

U.S. Department of Energy

Oak Ridge Operations Office

P.0. Box E

Oak Ridge, TN 37831

W. T. Mee

$\mathrm{Y}-12$

P.0. Box $Y$

Oak Ridge, TN 37830

D. C. Parzyck

Oak Ridge National Laboratory

P.0. Box $X$

Oak Ridge, TN 37830

B. G. Roach

Oak Ridge Associated Universities

P.0. Box 117

Oak Ridge, TN 37831

S. F. Seltzer

Paducah Gaseous Diffusion Plant

P.0. Box 1410

Paducah, KY 42001

3. Shoemaker

Oak Ridge Gaseous Diffusion Plant P.0. Box $P$

Oak Ridge, TN 37831

F. G. VanLoocke

RMI Company

P.0. Box 579

Ashtabula, $\mathrm{OH} \quad 44004$

E. R. Wagner

Portsmouth Gaseous Diffusion Plant

Martin Marietta Energy Systems

P.0. Box 628

Piketon, $\mathrm{OH} 45661$
No. of

Copies

DOE San Francisco Operations

Office

T. R. Crites

Lawrence Livermore National

Laboratory

P.0. $80 \times 5505$

Livermore, CA 94550

3. T. Davis

U.S. Department of Energy

San Francisco Operations Office

1333 Broadway

0akland, CA 94612

R. V. Griffith

Lawrence Livermore National

Laboratory

P.0. Box 5505

Livermore, CA 94550

W. E. Keheley

U.S. Department of Energy

San Francisco Operations Office 1333 Broadway

0akland, CA 94612

R. C. McCal1

Starford Linear Accelerator

P.0. Box 4349

Starford, CA 94305

P. L. Phelps

Lawrence Livermore National

Laboratory

P.0. Box 5505

Livermore, CA 94550

R. H. Thomas

DOE Lawrence Berkeley National Laboratory

University of California

Berkeley, CA 94720 
No. of

Copies

A. J. Toy

Lawrence Livermore National Laboratory

P.0. Box 808

Livermore, CA 94550

DOE Savannah River Operations

Office

D. N. Bridges

U.S. Department of Energy

Savannah River Operations Office P.0. Box A

Aiken, SC 29801

R. M. Hall

E.I. DuPont de Nemours \& Co.

Savannah River Plant

Aiken, SC 29809

W. A. Reese

U.S. Department of Energy

Savannah River Operations Office P.0. Box A

Aiken, SC 29801

W. C. Reinig

E.I. DuPont de Nemours \& Co.

Savannah River Plant

Aiken, SC 29809

EPA Office of Radiation Programs

A. Richardson

401 M Street, SW

Washington, DC 20460

National Center for Devices and Radiological Health

J. T. Lewis

Center for Dev. \& Radiol. Health

5600 Fishers Lane

Rockville, MD 20857

T. Ohthaber

Center for Dev. \& Radiol. Health

5600 Fishers Lane

Rockville, MD 20857
No. of

Copies

J. C. Vil1forth

FDA Bureau of Radiological Health

Rockville, MD 20852

National Bureau of Standards

R. Colle'

National Bureau of Standards

Gaithersburg, MD 20899

S. R. Domen

National Bureau of Standards

7309 Richters Mill Road

Derwood, MO 20855

E. H. Eisenhower

National Bureau of Standards

Ga ithersburg, MD 20899

H. T. Heaton, II

National Bureau of Standards

Gaithersburg, MD 20899

J. Hutchinson

National Bureau of Standards

Building 245, Room C114

Washington, DC 20234

K. Inn

National Bureau of Standards

Building 245, Room CI14

Washington, DC 20234

R. Loevinger

National Bureau of Standards

Gaithersburg, MO 20899

C. Reimann

National Bureau of Standards

Gaithersburg, MD 20899

R. B. Schwartz

National Bureau of Standards

Gajthersburg, MD 20899

P. Unger

National Bureau of Standards

Gaithersburg, MD 20899 
No. of

Copies

Nuclear Regulatory Commission

R. E. Alexander

U.S. Nuclear Regulatory Commission Washington, DC 20555

R. R. Bellamy

U.S. Nuclear Regulatory Commission 631 Park Avenue

King of Prussia, PA 19087

L. K. Cohen

U.S. Nuclear Regulatory Commission Washington, DC 20555

L. J. Cunningham

U.S. Nuclear Regulatory Commission washington, DC 20555

M. V. Federline

U.S. Nuclear Regulatory Commission Washington, DC 20555

K. R. Goller

U.S. Nuclear Regulatory Commission Washington, DC 20555

R. E. Minogue

U.S. Nuclear Regulatory Commission Washington, DC 20555

R. B. Neel

U.S. Nuclear Regulatory commission Wilste Bldg., MS-1130 SS

7515 Eastern Ave.

Silver Spring, MD 20912

L. C. Rouse

U.S. Nuclear Regulatory Commission Washington, DC 20555

Other

F. Bronson

Canberra/RMC

One State Street

Meriden, CT 06450
No. of

Copies

I. Fisenne

U.S. Department of Energy

Environmental Measurement

Laboratory

376 Hudson St.

New York, NY 10014

D. McCurdy

Yankee Atomic Electric Company 1671 Worcester Road

Framingham, MA 01701

R. Mellor

Yankee Atomic Electric Company

1671 Worcester Road

Frantingham, MA 01701

M. Ortiz

Eberijne Laboratories

P.0. Box 3874

Albuquerque, NM 87190

$R$. Wessman

EAL Corporation

203C Wright Ave.

Richmond, CA 94804

ONSITE

3 DOE Richland Operations Office

R. E. Gerton

K. H. Rising

J. i. Sutey

2 Westinghouse Hanford Company

L. K. ATdrich II

R. 0. Budd

2 U.S. Testing Company

M. M. Lardy

A. V. Robinson 
No. of

Copies

- 54 Pacific Northwest Laboratory

W. J. Bair

L. W. Brackenbush

G. W. R. Endres

T. H. Essig

L. G. Faust

D. R. Fisher

J. J. Fix

D. E. Hadlock

G. R. Hoenes

J. A. MacLel]an (10)

H. E. Palmer

W. D. Reece

R. I. Scherpelz (5)

J. M. Selby (15)

K. L. Soldat

M. J. Sula

K. L. Swinth

R. J. Traub

M. T. Upton

Heal th Physics Department Library

Publishing Coordination (2)

Technical Report Files (5) 
